\title{
1 The use of lithic assemblages for the definition 2 of short-term occupations in hunter-gatherer 3 prehistory
}

4 Nuno Bicho (ICArEHB, University of Algarve, Faro, Portugal) nbicho@ualg.pt

5 João Cascalheira (ICArEHB, University of Algarve, Faro, Portugal) jmcascalheira@ualg.pt

$6 \quad 2018-06-06$

7 One of the main elements in prehistoric research is the study of settlement patterns. In the last five decades,

8 stemming partially from Binford's research on the topic, the idea of settlement patterns is based on site typology,

9 including the traditional residential and logistic concepts. Both models of land use and exploitation are certainly

10 marked by the notion of short-term occupation. This concept, used freely by many archaeologists, tends to rely on

11 two main ideas: an occupation lasted a short span of time and resulted in a limited amount of material culture. Our

12 aim, based on our results from various archaeological case studies dated to the Upper Paleolithic of Portugal, is to

13 show that neither idea is necessarily correct: e.g. there may be short-term occupations with the production of large

14 amounts of artifacts, such as lithic workshops; there might be very small collections, such as lithic caches, resulting

15 from short occupations but with very long uses of the site; and most times, both are hardly differentiated within

16 complex palimpsests. Our study shows that the common use of lithic volumetric density and retouch frequency is

17 not always sufficient to differentiate between short and long-term occupations. Also, there are other variables that

18 are more sensitive to indicate the duration of occupation of an archaeological context that should be used in the

19 identification of time length.

\section{The archaeological use of 'Short-term occupation'}

21 Prehistoric archaeology has been fighting hard to understand the archaeological record and how

22 it relates to past human evolution and anthropogenic adaptations to the changing environment.

23 The development of actualistic studies (sensu Binford 1981) in the last half century, including

24 such specialized disciplines as Ethnoarchaeology, Geoarchaeology or Zooarchaeology, have

25 greatly helped us to understand, not only the archaeological material culture, but also site

26 formation processes (e.g. Schiffer 1983, 1987) in a wide and very diversified manner.

27 Nevertheless, archaeologists still endure complex problems for the definition of universally used

28 concepts related to past human adaptations. In some cases, however, archaeologists just freely

29 use those concepts without the necessary careful or proper consideration of their meaning and the 
impact that they might have in further interpretations of the distant past. The concept of 'shortterm occupation' seems to be such a case. The idea of short-term occupation has been frequently used to succinctly describe site's or lithic assemblage's characteristics (e.g. Porraz 2009; Rios-

33 Garaizar 2016; Picin 2017). Most times, it is, in one way or another, related to work on

34 settlement patterns, starting with the classic Binford' studies on the Nunamiut settlement system and related discussion of site structuring and intra-site spatial organization (e.g. Binford 1978a, 1978b, 1982), as well as on hunter-gatherer mobility research (e.g. Binford 1980; Kuhn 1992; Kelly 1995; Amick 1996; Barton and Riel-Salvatore 2014; Nishiaki and Akazawa 2015).

In 1972, Sahlins (1972) argued that, if given enough time, a small group of foragers can rapidly deplete the resources within a short range from their residential base camp. This basic assumption is fundamental to understand the value of the definition of a short-term occupation for hunter-gatherer research, and more so in the case of the prehistoric archaeological record. As Yellen (1977) stated, the duration of occupation of a group in a specific ecological context will affect both the quantity and nature of the archaeological record visible at a site. The issue, then, is to juggle a series of variables, including duration of occupation and population size, and to make sense of the results, so the concept is clear and used in a meaningful manner.

As Moncel and Rivals (2011) have argued, it is not always easy to make a distinction between long-term and short-term occupations. While ethnographically this distinction might be easy to demonstrate, although most certainly corresponding to a continuum as both Yellen (1977) and Binford (1978a) have shown in their ethnoarchaeological studies, in the archaeological record this task is certainly more complex. There are a set of cultural variables that have a direct impact on the duration of any occupation. The most important are likely to be population size, habitat quality (or in other words, local ecological diversity and carrying capacity), diversity and type of

53 functions at the site. These, unfortunately, cannot be measured directly in the archaeological

54 record and we need proxies that helps us to understand the diversity of each at every single site and even in individual contexts at each site. While in the case of population size there has been attempts to produce numerical formulae to resolve the issue (e.g. Grove 2009), the most common variable used to define the size of a population at a site is the dimension of the site. The measurement of the habitat quality is certainly more problematic and is limited to organic data

59 (i.e., fauna and flora in all possible formats) and raw materials, present at the site. Site diversity 
60 and type of functions have traditionally been measured based on, respectively, tool diversity

61 indices, and use-wear and residue analyses. In addition to tool diversity, the presence, quantity,

62 and diversity of habitat features is also commonly used for determining site function (Table 1).

63

Table 1 Traditional criteria for estimation of duration of occupation

\begin{tabular}{lll} 
Archaeological Variables & Short-term occupation & Long term-occupation \\
\hline Site area & Small & Large \\
Artifact numbers & Small & High \\
Artifact density & Low & High \\
Frequency of retouch & High & Low \\
Tool diversity & Low & High \\
Number of features & Low & High \\
Thickness of Archaeological deposits & Thin & Thick \\
Spatial segregation of activities & Rare & Frequent
\end{tabular}

66 The use of the concept of short-term (and also that of long-term) occupations is directly related,

67 in the archaeological literature, with site typology. Terms such as Residential site, Residential

68 camp, Logistical camp, Base camp, and many others are frequently applied with no particular

69 verified criteria other than the size of the site, or of the dimension and diversity of the artefactual

70 assemblage (e.g. Madsen et al. 2006; Porraz 2009; Crassard et al. 2013; Rios-Garaizar 2016;

71 Bretzke et al. 2017; Terradillos-Bernal et al. 2017). Other studies have furthered improved those

72 concepts, with both descriptions of criteria and their application (e.g. Barton 1990; Dillehay et al.

73 2011; Nishiaki and Akazawa 2015; Clark and Barton 2017).

74 In Binford's seminal framework there are clear definitions of site typology (Binford 1980) that

75 relate to mobility patterns: "For foragers, I recognized two types of site, the residential base

76 camp and the location. Collectors generate at least three additional types of sites by virtue of the

77 logistical character of their procurement strategies. These I have designated the field camp, the

78 station, and the cache." (Binford 1980: 10).

79 Another good example of site nomenclature is that of Dillehay et al. (2011) for the foraging-

80 farming transition in the Andes. The authors indicate the presence of a very diverse and

81 expanded site typology (Dillehay et al. 2011: 36-40), defining long-term and short-term base and 
82 field camps, processing stations, transitory station/workshops, lithic quarries, earthen mounds,

83 horticultural residences with gardens, permanent residences associated with irrigation,

84 agriculture, hillside villages and special activity locales.

85 These examples start with a basic assumption that "...the greater the number of generic types of

86 functions a site may serve, the greater the number of possible combinations, and hence the

87 greater the range of inter-site variability...” (Binford 1980: 12). However, as Binford also

88 argued, there is considerable variability in the duration of each stay in each site and the type of

89 mobility pattern present (Binford 1980), and thus each site may have been used for different

90 functions and durations (Binford 1982), with a direct impact on the archaeological visibility of

91 sites and their respective duration cycle. Barton and colleagues (Riel-Salvatore and Barton 2004;

92 Barton and Riel-Salvatore 2014; Clark and Barton 2017), following Binford's perspective, have

93 argued for a continuum in the use of space and time between residential (Foragers) and logistical

94 (Collectors) patterns, that can be measured in the archaeological record using the relationship

95 between artifact volumetric density and the frequency of retouched tools within each assemblage

96 - named by the authors as the Whole Assemblage Behavioral Index (WABI). The index is

97 expected to show a negative correlation between both variables, reflecting accumulated artifacts

98 deriving from primarily curated to primarily expedient artifact use. Although the authors

99 emphasize that "the terms "expedient" and "curated" do not reflect individual site-occupation

100 events" (Riel-Salvatore and Barton 2007: 62). They also assume that expedient assemblages

101 often accumulate at more intensively occupied sites, while curated assemblages more usually

102 derive from short-term occupations.

103 In this study, we focus on previous uses of the term short-term occupations and its definitions,

104 and the parent archaeological proxies used to define length of site occupation as well as site type.

105 Using data from various case studies we have been working with over the past 25 years, we

106 critically evaluate the application of the WABI proxy and explore a combination of other

107 potential variables for the definition of occupation duration using commonly available stone tool

108 and context data. 
$110 \quad$ Case studies

111 We used in this study a total of 17 stone tool samples from different archaeological contexts, 112 coming from a set of various sites excavated since the late 1980's: Areeiro I (Bicho 1992, 1993, 113 1994) Cabeço do Porto Marinho (Bicho 1992, 1994), Carneira II (Bicho 1992, 1993), Picareiro

114 (Bicho et al. 2006), Pinhal da Carneira (Bicho 1992, 1993), and Quinta do Sanguinhal (Bicho

115 2005) in central Portugal, and Vale Boi (Cascalheira and Bicho 2013, 2015; Bicho et al. 2017b)

116 in southern Portugal. In most cases, only samples were used, instead of whole assemblages, since 117 only those have been published.

118 Areeiro I (ARI) was excavated in 1987 (Marks et al. 1994). It is located in the Rio Maior area, in 119 a region with the highest concentration of open-air sites in the Portuguese Upper Paleolithic. It 120 was found in sands, as all the Rio Maior sites in the present paper. Excavation was carried out by 121 artificial $10 \mathrm{~cm}$ spits and all sediment was screened through a $2 \mathrm{~mm}$ mesh. Artifacts are slightly 122 damaged by a modern fire. No habitat features were found at the excavated area (Table 2), but 123 the density of artifacts and the apparent extension of the deposit suggested a medium to long124 term residential occupation. 


\begin{tabular}{|c|c|c|c|c|c|c|c|c|c|c|c|c|c|c|c|c|c|}
\hline Sites & $\begin{array}{l}\text { Estimat } \\
\text { edArea }\end{array}$ & $\begin{array}{r}\text { Deposit } \\
\text { Thickn } \\
\text { ess }\end{array}$ & $\begin{array}{r}\text { Sample } \\
\text { dVolu } \\
\text { me }\end{array}$ & $\begin{array}{r}\text { Artifact } \\
\mathrm{s}\end{array}$ & Cores & Blanks & Chips & $\begin{array}{r}\text { Retouc } \\
\text { hedToo } \\
1 \mathrm{~s}\end{array}$ & $\begin{array}{r}\text { ToolTy } \\
\text { pes }\end{array}$ & $\begin{array}{r}\text { Feature } \\
\mathrm{s}\end{array}$ & $\begin{array}{r}\text { LithicD } \\
\text { ensity }\end{array}$ & $\begin{array}{r}\text { CoreFr } \\
\text { eq }\end{array}$ & $\begin{array}{r}\text { Blanks } \\
\text { Freq }\end{array}$ & $\begin{array}{r}\text { ChipsF } \\
\text { req }\end{array}$ & $\begin{array}{r}\text { Retouc } \\
\text { hFreq }\end{array}$ & $\begin{array}{l}\text { ToolDi } \\
\text { versity }\end{array}$ & $\begin{array}{r}\text { Feature } \\
\text { sFreq }\end{array}$ \\
\hline AR I & 50 & 0.25 & 0.50 & 2048 & 84 & 890 & 849 & 204 & 38 & 0 & $\begin{array}{r}4096.0 \\
0\end{array}$ & 0.04 & 0.43 & 0.41 & 0.10 & 2.66 & 0.00 \\
\hline $\begin{array}{l}\text { CPM } \\
\text { III } \\
\text { Trench }\end{array}$ & 8 & 0.15 & 0.45 & 1487 & 24 & 807 & 529 & 90 & 35 & 1 & $\begin{array}{r}3304.4 \\
4\end{array}$ & 0.02 & 0.54 & 0.36 & 0.06 & 3.69 & 2.22 \\
\hline $\begin{array}{l}\text { CPM I } \\
\text { Upper }\end{array}$ & 70 & 0.35 & 1.40 & 4703 & 217 & 1601 & 1241 & 1481 & 72 & 0 & $\begin{array}{r}3359.2 \\
9\end{array}$ & 0.05 & 0.34 & 0.26 & 0.31 & 1.87 & 0.00 \\
\hline $\begin{array}{l}\text { CPM II } \\
\text { Upper }\end{array}$ & 70 & 0.25 & 1.00 & 2393 & 34 & 1180 & 925 & 187 & 43 & 0 & $\begin{array}{r}2393.0 \\
0\end{array}$ & 0.01 & 0.49 & 0.39 & 0.08 & 3.14 & 0.00 \\
\hline $\begin{array}{l}\text { CPM II } \\
\text { Middle }\end{array}$ & 40 & 0.25 & 1.75 & 2260 & 41 & 1047 & 995 & 120 & 37 & 0 & $\begin{array}{r}1291.4 \\
3\end{array}$ & 0.02 & 0.46 & 0.44 & 0.05 & 3.38 & 0.00 \\
\hline $\begin{array}{l}\text { CPM I } \\
\text { Lower }\end{array}$ & 70 & 0.30 & 2.10 & 1766 & 78 & 843 & 585 & 202 & 45 & 1 & 840.95 & 0.04 & 0.48 & 0.33 & 0.11 & 3.17 & 0.48 \\
\hline $\begin{array}{l}\text { CPM } \\
\text { III } \\
\text { Upper }\end{array}$ & 60 & 0.25 & 0.75 & 2148 & 90 & 1047 & 699 & 268 & 50 & 0 & $\begin{array}{r}2864.0 \\
0\end{array}$ & 0.04 & 0.49 & 0.33 & 0.12 & 3.05 & 0.00 \\
\hline $\begin{array}{l}\text { CPM } \\
\text { III S }\end{array}$ & 100 & 0.35 & 1.40 & 5179 & 75 & 2597 & 1841 & 382 & 55 & 2 & $\begin{array}{r}3699.2 \\
9\end{array}$ & 0.01 & 0.50 & 0.36 & 0.07 & 2.81 & 1.43 \\
\hline CPM V & 50 & 0.20 & 1.80 & 2701 & 33 & 1033 & 1397 & 162 & 39 & 0 & $\begin{array}{r}1500.5 \\
6\end{array}$ & 0.01 & 0.38 & 0.52 & 0.06 & 3.06 & 0.00 \\
\hline CR II & 100 & 0.25 & 1.50 & 2151 & 46 & 1264 & 607 & 171 & 41 & 1 & $\begin{array}{r}1434.0 \\
0\end{array}$ & 0.02 & 0.59 & 0.28 & 0.08 & 3.14 & 0.67 \\
\hline PC & 100 & 0.25 & 1.00 & 2431 & 29 & 956 & 1148 & 205 & 41 & 0 & $\begin{array}{r}2431.0 \\
0\end{array}$ & 0.01 & 0.39 & 0.47 & 0.08 & 2.86 & 0.00 \\
\hline QS & 5 & 0.05 & 0.25 & 1438 & 8 & 378 & 975 & 8 & 2 & 0 & $\begin{array}{r}5752.0 \\
0\end{array}$ & 0.01 & 0.26 & 0.68 & 0.01 & 0.71 & 0.00 \\
\hline $\begin{array}{l}\text { VB } \\
\text { Shelter } \\
2\end{array}$ & 2 & 0.50 & 1.00 & 54 & 0 & 8 & 13 & 31 & 3 & 0 & 54.00 & 0.00 & 0.15 & 0.24 & 0.57 & 0.54 & 0.00 \\
\hline $\begin{array}{l}\text { VB } \\
\text { Shelter } \\
\text { Z }\end{array}$ & 8 & 0.15 & 0.90 & 1156 & 22 & 323 & 581 & 33 & 15 & 0 & $\begin{array}{r}1284.4 \\
4\end{array}$ & 0.02 & 0.28 & 0.50 & 0.03 & 2.61 & 0.00 \\
\hline $\begin{array}{l}\text { VB } \\
\text { Shelter } \\
\text { B }\end{array}$ & 30 & 0.25 & 6.00 & 12819 & 80 & 2304 & 7867 & 141 & 31 & 1 & $\begin{array}{r}2136.5 \\
0\end{array}$ & 0.01 & 0.18 & 0.61 & 0.01 & 2.61 & 0.17 \\
\hline $\begin{array}{l}\text { Picareir } \\
\text { o F/G }\end{array}$ & 25 & 0.35 & 5.60 & 1954 & 19 & 261 & 1510 & 121 & 43 & 1 & 348.93 & 0.01 & 0.13 & 0.77 & 0.06 & 3.91 & 0.18 \\
\hline
\end{tabular}


127 Cabeço do Porto Marinho (CPM) was excavated between 1987 and 1994 (Bicho 1992; Marks et

128 al. 1994). CPM is one of the largest Portuguese Upper Paleolithic sites with a very long

129 archaeological sequence. There are over 30 different stratigraphical contexts starting with early

130 Gravettian, Proto-Solutrean, Magdalenian, Epipaleolithic, Neolithic and Bronze Age occupations

131 (Bicho 1992; Marks et al. 1994; Zilhão 1997). For this study we used various horizons, known as

132 CPM I Lower, I Upper, II Middle, II Upper, III Upper, III South, III Trench, and V, respectively

133 coming from loci I, II, III and V. All assemblages are dated to the Magdalenian and

134 Epipaleolithic, between c. 20 and $9 \mathrm{ka}$ cal BP. Artifact retrieval resulted from excavation based

135 on artificial 5 or $10 \mathrm{~cm}$ spits and all sediment was screened with a $2 \mathrm{~mm}$ mesh, but only CMP III

136 trench was fully excavated. Some of those contexts had, at least, an in situ hearth (Bicho 1992).

137 Data from each context is presented in Table 2, but the lithic assemblages have between c. 1500

138 artifacts (CPM III Trench) and >10 000 artifacts (CPM I Upper), although only the samples

139 studied by Bicho (1992) were used in the present study. With the exception of CPM III Trench,

140 corresponding to a small area around a single hearth, all other contexts were thought to represent

141 middle to long-term occupations, likely residential base camps.

142 Carneira II (CR II) and Pinhal da Carneira (PC) are sites in the same general pine grove outside

143 Rio Maior city. They are both single layered sites with an average of 20-25 cm thick deposit.

144 There is a hearth in CR II, but no features were found in the small excavated area of PC.

145 Excavation was carried out in $10 \mathrm{~cm}$ artificial spits and all sediment was screened with a $2 \mathrm{~mm}$

146 mesh. Both sites are dated to the Epipaleolithic, respectively c. 10.5 and 11.5 cal BP (Bicho

147 1992, 1994). Lithic assemblages used in this study are samples from the excavated area (Table

148 2). Both horizons, based on the amount of artifacts, were thought to be middle to long-term

149 occupations, likely residential base camps.

150 Quinta do Sanguinhal (QS) is a very small open air site, also in the Rio Maior region (Bicho

151 2005). It is a Gravettian occupation, fully excavated with a total of $6 \mathrm{~m} 2$ (although it may have

152 been slightly larger but, when we found the site, the western section had been removed due to

153 construction of a building). The assemblage is composed of c. 1500 artifacts (Table 2) and there

154 are several refittings. No features were found in the excavated area. Based on the lithic

155 assemblage, the occupation was thought to correspond to a single short-term blade production 
156 site, with very few tools and cores, with many blades missing from the sequence, as shown by 157 reffiting (Almeida 2000; Bicho 2005).

158 The cave site of Picareiro is located in central Portugal. The cave was excavated between 1994 159 and 2001 (PI Nuno Bicho) and a second project started in 2005 and is still underway under the 160 direction of Jonathan Haws. The cave has a very long sequence of more than 9 meters and has 161 archaeological horizons dated from the Middle Paleolithic to the Bronze Age (Bicho et al. 2006; 162 Haws 2012). The lithic assemblage used here dates to the Magdalenian and is associated to a 163 very large hearth (Bicho et al. 2006). This specific occupation was thought to correspond to a 164 meat drying and smoking logistical station. It seems to be a very specialized industry composed 165 mostly of chipage, a few cores, and small backed bladelets (both points such as microgravettes, 166 and simple backed pieces). The sample is close to 2000 artifacts (Table 2).

167 The site of Vale Boi was discovered in 1998 and excavation started in 2000 (Bicho et al. 2004, 168 2013). There are four different loci (Terrace, Slope, Rock Shelter and Rock Shelter 2) with 169 archaeological horizons dated to the early Gravettian (Bicho et al. 2015, 2017a), Solutrean and 170 Magdalenian, while one of those loci (VB Terrace) has also Mesolithic and early Neolithic 171 occupations (Carvalho 2007; Bicho 2009). Excavation followed detailed 3D location of artifacts 172 using a Total station and full sediment screening with a 2-3 $\mathrm{mm}$ mesh screen.

173 The oldest assemblage is early Gravettian. It is a particular setting found at the bottom of VB 174 Rock Shelter 2, composed by only 54 artifacts and coming from an area slightly smaller than 2 $175 \mathrm{~m} 2$. It likely corresponds to a Gravettian point cache (Bicho et al. 2016), since the large majority 176 of the recovered artifacts are backed pointed bladelets.

177 The other two assemblages (VB Shelter B and Z) are from the rock shelter locus, respectively 178 dated to the Solutrean and Magdalenian (Mendonça 2009; Cascalheira 2013; Cascalheira and 179 Bicho 2015). No habitat features were found in the small Magdalenian horizon but a small hearth 180 was found in the middle of the excavated area of the VB B Solutrean Layer (Table 2).

$181 \quad$ Variables

182 The literature referenced before indicates as the main archeological variables for the definition of 183 the duration of occupation, artifact and tool density (Barton and Riel-Salvatore 2014; Clark and 
184 Barton 2017), expressed as retouch frequency and lithic volumetric density (artifacts per cubic 185 meter). Logistically base camps and short-term camps were recognized by Clark and Barton 186 (2017) based on the correlation of those two variables, producing a table of reference of material 187 correlates of mobility. Short-term camps represent overnight and limited activities of small 188 groups out from logistically base camps or larger groups based on a regular residential moving 189 pattern. The result is a high incidence of retouch but with low lithic volumetric density, high 190 lithic curation, low numbers of cores and debitage, and small archaeological contexts. In 191 contrast, sites with large residential stability, named by those authors as logistically organized 192 base camps, are marked by high lithic densities, low incidence of retouch, high numbers of non193 exhausted cores, high numbers of blanks, large sites and what are usually called expedient 194 technologies and assemblages.

195 There are, however, other variables that have been listed as possibly indicative of duration of 196 occupation. These include site area, number of features, and spatial segregation of activities (e.g. 197 Binford 1980; Dillehay et al. 2011; Nishiaki and Akazawa 2015). In the present study we use all 198 of the above variables, so we can test their usefulness as a measure of time of occupation in 199 archaeological contexts:

200 - Site area - the total area of an occupation visible in the archaeological context. Here we 201 present three cases for each site, all in m2: estimated area of occupation, excavated area, 202 and sampled area of the lithic assemblage used in the study;

203 - Thickness of the Deposit - average thickness of the excavated deposit presented (in 204 meters), where the lithic assemblage and associated features were recovered;

205 - Sampled Volume: Volume of excavated sediments from the sampled area, presented in m3;

206 - Number of artifacts - total number of analyzed artifacts in the lithic sample;

207 - Lithic Density - estimated number of artifacts present in one cubic meter of sediment 208 (following Clark and Barton (2017));

209 - Cores - numbers of cores present in the lithic sample;

210 - Core Frequency - relative frequency of cores in the lithic sample; 
211 - Blanks - numbers of blanks (flakes, blades and bladelets) present in the lithic sample;

212 - Blank Frequency - relative frequency of blanks in the lithic sample;

213 - Chips - numbers of chips (artifacts smaller than $1 \mathrm{~cm}$ ) present in the lithic sample;

214 - Chip Frequency - relative frequency of chips (artifacts smaller than $1 \mathrm{~cm}$ ) in the lithic 215 sample;

216 - Retouched Tools - total number of artifacts with retouch in the lithic sample;

217 - Retouch Frequency - relative frequency of retouched artifacts in the lithic sample 218 (following Clark and Barton (2017));

219 - Tool Types - number of tool types following the adapted (Bicho 1992; Zilhão 1997)

220 traditional Upper Paleolithic Typology (de Sonneville-Bordes and Perrot 1954, 1955, $221 \quad 1956 b, 1956 a)$;

222 - Tool diversity - diversity of tool types within each assemblage, calculated using the 223 Menhinick's index in which the number of tool types represented is divided by the square 224 root of the total number of retouched tools;

225 - Number of Features - number of features associated to the specific archaeological context 226 from which the lithic assemblage was recovered;

227 - Features Frequency - relative frequency of features for the sampled volume of sediment.

228 Statistics

229 Principal Component Analysis (PCA) is a commonly used technique to extract relevant 230 information from a multivariate dataset and to express this information as a set of few new 231 variables called principal components or dimensions. The usefulness of PCA is that, in a single

232 analytical process, one can indicate relationships between and within variables and cases, suggest 233 general trends in data structure and identify which variables best explain these patterns, compress

234 large percentages of variance from a wide set of variables in a reduced number of factors, and

235 perform this transformation so that the new variables are not correlated and therefore do not 236 present redundant information (Shennan 1997). PCA has had numerous applications in 
237 Archaeology (e.g. McPherron 1994; McCall 2006, 2007; Marreiros and Bicho 2013) and is

238 available through most of the statistical software packages.

239 Here, we applied PCA to our dataset to identify possible correlations between variables that

240 would indicate the existence of patterns that, when compared with a priori information from each

241 of the sites, could possibly be translated into more secure proxies for occupation duration.

242 All analyses and data processing were accomplished in R (version 3.4.4) (R Core Team 2013).

243 PCA analysis was performed using the FactoMineR package (Lê et al. 2008). Following recent

244 concerns on the reproducibility of archaeological analysis we include the entire R code used for

245 all the analysis and visualizations contained in this paper in our supplemental online material 246 (SOM) at https://dx.doi.org/10.17605/OSF.IO/J39SU. To produce those files we followed the

247 procedures described by Marwick et al. (2017) for the creation of research compendiums to 248 enhance the reproducibility of research. The files provided contain all the raw data used in our 249 analysis as well as a custom R package (Wickham 2015) holding the code use for all analysis 250 and to produce all tables and figures. To enable maximum re-use, our code is released under the 251 MIT license, our data as CC-0, and our figures as CC-BY, (for more information see Marwick 252 2016).

\section{Results}

254 Looking at the traditional criteria for estimation of duration of occupation listed in Table 1, the 255 results are, in some cases, different from what we expected based on the field interpretations for 256 each context. Results are presented in Table 2. Site area is relatively low for all loci, ranging 257 from just a few square meters to 50-70 $\mathrm{m} 2$, with just a few locations reaching close to $100 \mathrm{~m} 2$. 258 Deposit thickness is also fairly low, between 5 and $35 \mathrm{~cm}$ thick, but mostly around 20 to $25 \mathrm{~cm}$. 259 Most sites present a medium to high Lithic Density, while Retouch Frequency is, in most cases, 260 very low (less than 1\%). Tool Diversity, with very few exceptions, such as CPM III Trench and 261 VB Shelter 2, with ratios close to 0.4, tend to be medium to low with several results lower than 2620.2 . Features are mostly absent and in the cases that are present are small hearths. The exceptions 263 are CPM IIIS with a possible stone pavement and a hearth, and Picareiro F/G layer with the 264 presence of a very large hearth (over 2 meters in diameter) made of large limestone slabs and 265 clearly object of carefully cleaning and reuse. 
266 Those seven criteria tend to suggest that under traditional classifications, although not without

267 doubts, most of the case studies would be classified as long-term base camp occupations, such as

268 ARI, CPM III Trench, CMP II Upper, CPM II Middle, CMPS IIIS and QS. On the contrary, VB

269 Shelter 2 and CPM III Upper, seem to be the only two contexts that would be unequivocally

270 classified as short-term occupations. In the other nine cases, the criteria do not seem to help to

271 define the duration of the occupation.

272 This empirical classification is only partially in agreement with the evidence available from

273 previous studies on the lithic and general archaeological context of each site.

274 When we plot lithic volumetric density against retouch frequency, following Clark and Barton

275 (2017) index, the results are generically as expected (Figure 1). The correlation displayed

276 between both variables is negative, with most of the sites concentrated in the lower right side of

277 the graph, suggesting the presence of a majority of contexts with expedient organization of the

278 lithic technology, and thus, most likely corresponding to long-term base camps. The opposite

279 corner of the chart (upper left) is populated by a single isolated context, VB Shelter 2, which,

280 according to previous interpretations, is in fact a short-term logistical stone tool cache. More

281 interesting, though, is the location of a set of three contexts (QS, VB Shelter Z and Picareiro

$282 \mathrm{~F} / \mathrm{G}$ ) towards the bottom right of the chart, for which previous lithic analysis and context

283 characterization suggested the presence of short-term occupations.

284 This pattern seems to suggest that the WABI approach is viable but may be insufficient to 285 accurately identify the whole range of short-term occupations possibly present in the context of 286 logistical settlement systems. To address this problem, we applied a multivariate approach to the 287 same assemblages, by including a larger set of variables that have been considered significantly 288 related to mobility patterns and, consequently, with the duration and nature of each occupation. 


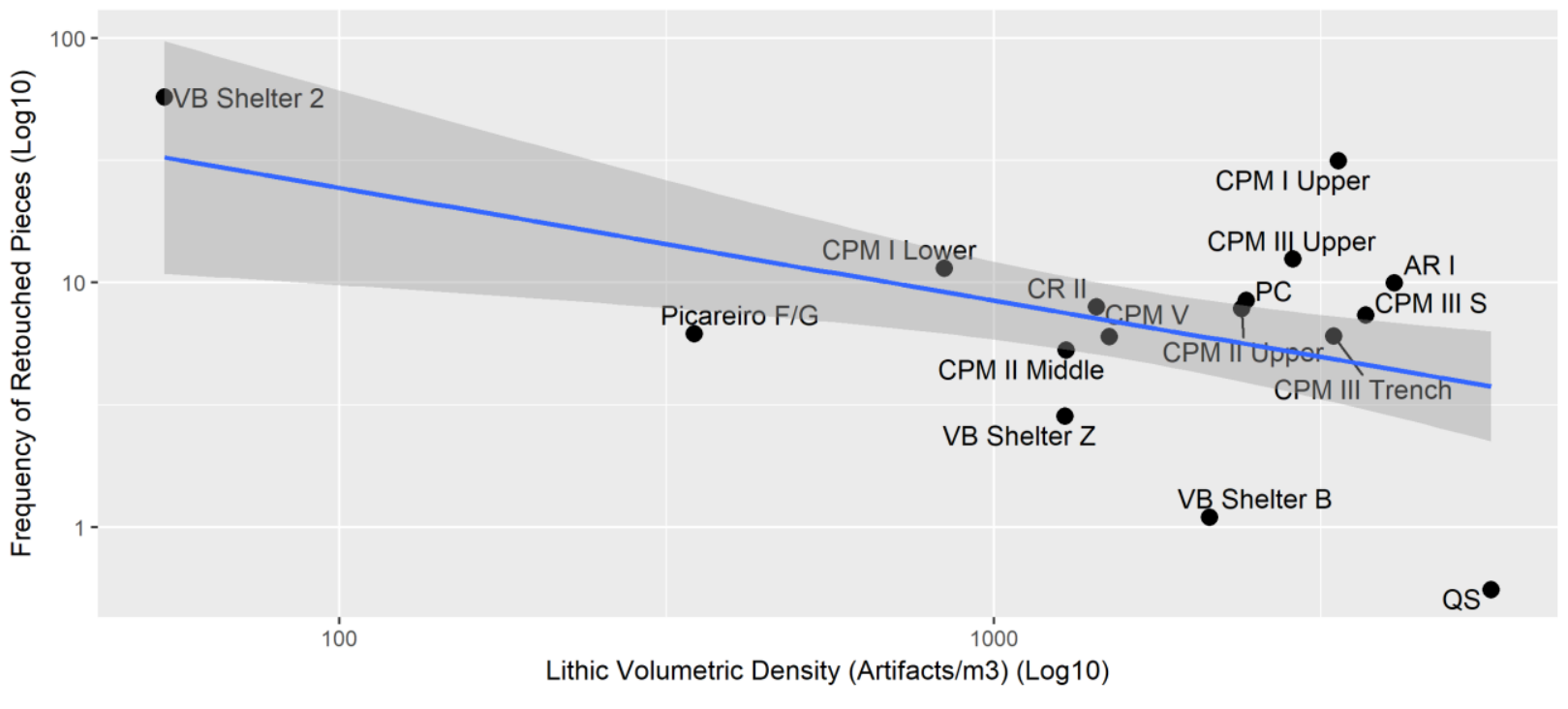

291 Figure 1 Whole Assemblage Behavioral Index

293 As a result, running PCA with the enlarged set of criteria provides a slightly different perspective 294 on the WABI patterns. Four of the calculated PCA dimensions present eigenvalues higher than 1, 295 explaining more than $87 \%$ of dataset variability (Table 3). Dimensions 1 and 2, alone, explain 296 over $58 \%$ of the variability.

298 Table 3 Eigen values and percentage of variance for each dimension of PCA

\begin{tabular}{lrrr} 
& eigenvalue & variance.percent & cumulative.variance.percent \\
\hline Dim.1 & 2.764 & 34.555 & 34.555 \\
Dim.2 & 1.940 & 24.252 & 58.808 \\
Dim.3 & 1.246 & 15.578 & 74.386 \\
Dim.4 & 1.076 & 13.455 & 87.841 \\
Dim.5 & 0.607 & 7.582 & 95.422 \\
Dim.6 & 0.256 & 3.202 & 98.624 \\
Dim.7 & 0.084 & 1.052 & 99.676 \\
Dim.8 & 0.026 & 0.324 & 100.000
\end{tabular}

300 Figure 2 clearly show that a total of three variables with contributions larger than the expected 301 average cut off value are in the origin of the compression represented by Dimension 1: Blank 
Frequency (c. 32\%), site Estimated Area (c. 19\%), and Core Frequency (c. 13\%). Dimension 2 is mostly explained by Retouch Frequency (c. 42\%), Chip Frequency (c. 32\%), and Tool Diversity (c. 15\%). Finally, Dimensions 3 and 4 are largely explained by a single variable, that in the first case is Lithic Density (c. 72\%) and in the second Features Frequency (c. 60\%).
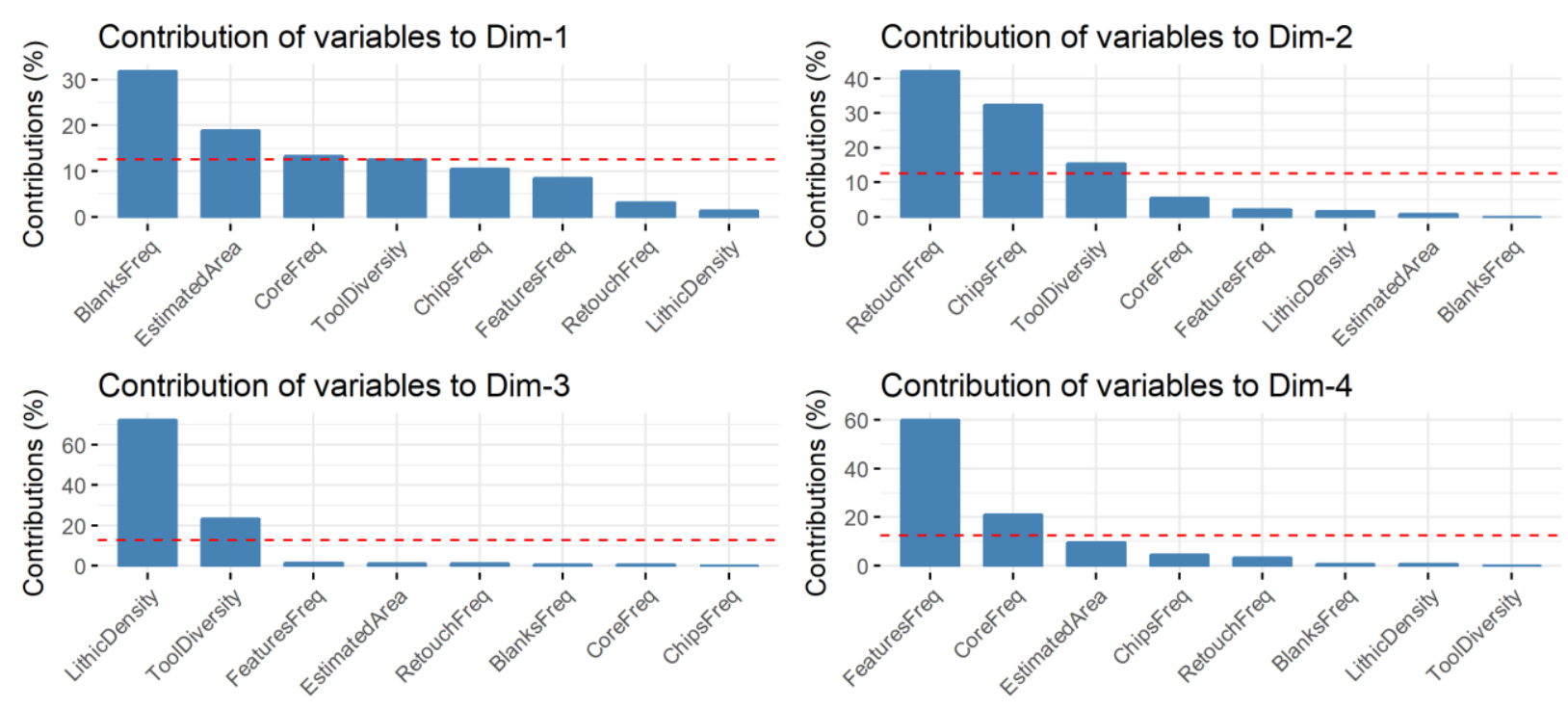

Figure 2 Contribution of variables for each of the four relevant PCA dimensions

310 When plotted into bi-dimensional correlation plots (Figure 3), Dimension 1 is clearly marked by 311 a positive correlation between all the relevant variables, while Dimension 2 is mostly marked by 312 a negative correlation between Retouch Frequency and the other two major contributors: Chip 313 Frequency and Tool Diversity.

314 In the case of Dimensions 3 and 4, correlations seem to be less marked, mostly due to the low 315 contribution of many variables. However, it is still noteworthy the negative correlation between 316 Lithic Density and Tool Diversity, on the one hand, and the negative correlation between 317 Features Frequency and Core Frequency, on the other hand. 


\section{Correlation plot: Dim1/Dim2}

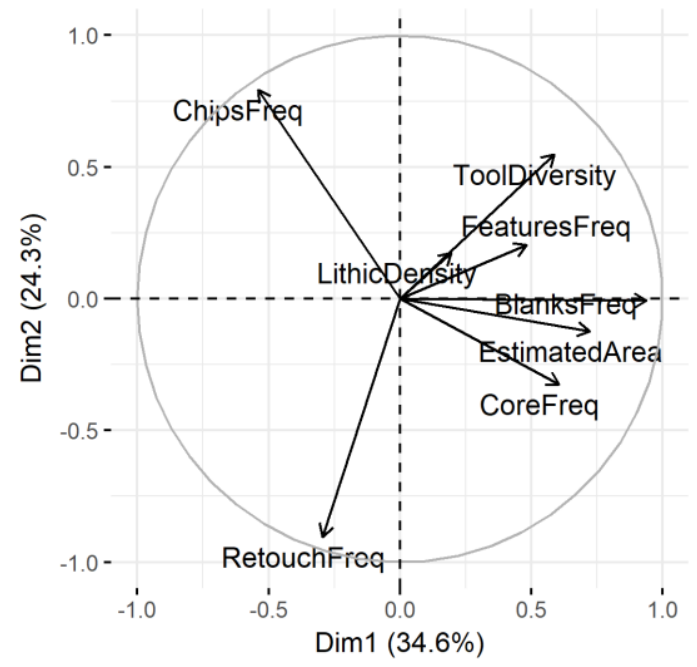

Correlation plot: Dim3/Dim4

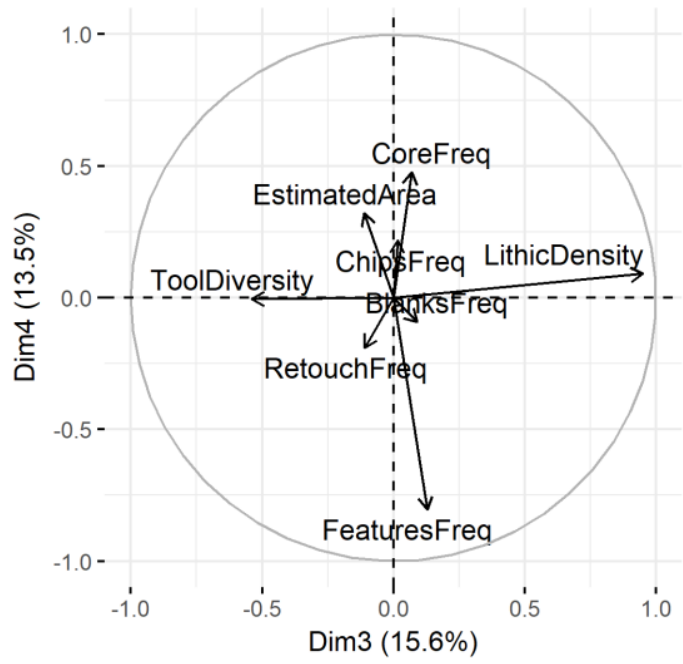

Figure 3 Correlation plots of variables for each of the four relevant PCA dimensions

322 Figures 4 and 5 present the biplot charts of each pair of PCA dimensions, representing, in a

323 single space, the association between variables and cases. The location of contexts using the first 324 two dimensions (Table 4) seems to confirm the WABI results (Figure 1) by (1) isolating VB

325 Shelter 2 from the remaining group due to a very high frequency of retouched tools and low 326 numbers of every other variable, but also (2) by separating the cluster of sites - Picareiro F/G, 327 QS, VB Shelter Z, and VB Shelter B - whose locations in the WABI plot were outside the 80\% 328 confidence interval based on all the remaining sites. The relevant outcome, though, is that these 329 contexts appear now associated with larger values of Chip Frequency and low values of all the 330 remaining variables, and not clearly associated with expedient base camps as suggested by the 331 WABI. The use and relevance of Chip Frequency in this analysis might raise some concerns due 332 to the possible influence of preservation conditions and post-depositional processes affecting 333 each context. For this reason, during our exploratory analysis we recalculate the PCA without 334 using Chip Frequency, and results came out essentially the same in terms of the location of 335 contexts within each dimension (although we do not present the outcomes of these extra336 analysis, they can be confirmed by using the code provided in our SOM materials).

337 Overall, the combination of Dimensions 1 and 2 seems to provide a more detailed separation 338 between contexts with shorter and longer occupations than with WABI. The division between 
339 contexts is not as much explained by lithic volumetric density, as it is by the frequencies of the

340 three different technological classes (chips, blanks and cores) used, as well as by the diversity of

341 retouched tools types.

342 The association between contexts and variables across Dimension 3 and 4 is more difficult to

343 interpret, given that only a small number of variables offers significant explanatory power. Yet,

344 it is rather clear, once again, that Lithic Density is not, by itself or in conjunction with Retouch

345 Frequency, a consistent proxy for duration of occupation. The location of QS in the far right

346 extreme of Figure 4, associated with high values of lithic volumetric density and low frequency

347 of retouched tools clearly corroborates this idea.

348

349 Table 4 PCA coordinates for the archaeological contexts

\begin{tabular}{lrrrr} 
& Dim.1 & Dim.2 & Dim.3 & Dim.4 \\
\hline AR I & 0.79 & -0.29 & 1.14 & 1.15 \\
CPM III Trench & 1.62 & 1.09 & 0.65 & -2.99 \\
CPM I Upper & 0.49 & -2.44 & 0.86 & 1.01 \\
CPM II Upper & 0.75 & 0.15 & -0.24 & 0.32 \\
CPM II Middle & 0.26 & 0.50 & -0.90 & 0.23 \\
CPM I Lower & 1.63 & -0.74 & -0.98 & 0.47 \\
CPM III Upper & 1.38 & -0.73 & 0.18 & 0.99 \\
CPM III S & 1.91 & 0.27 & 0.88 & -1.16 \\
CPM V & -0.38 & 0.72 & -0.71 & 0.30 \\
CR II & 2.17 & -0.39 & -0.69 & -0.28 \\
PC & 0.38 & 0.29 & -0.23 & 0.71 \\
QS & -2.48 & 1.17 & 3.12 & 0.32 \\
VB Shelter 2 & -3.42 & -3.68 & -0.65 & -1.55 \\
VB Shelter Z & -1.29 & 0.60 & -0.48 & 0.20 \\
VB Shelter B & -1.81 & 1.38 & -0.10 & 0.08 \\
Picareiro F/G & -2.02 & 2.12 & -1.85 & 0.21 \\
\end{tabular}




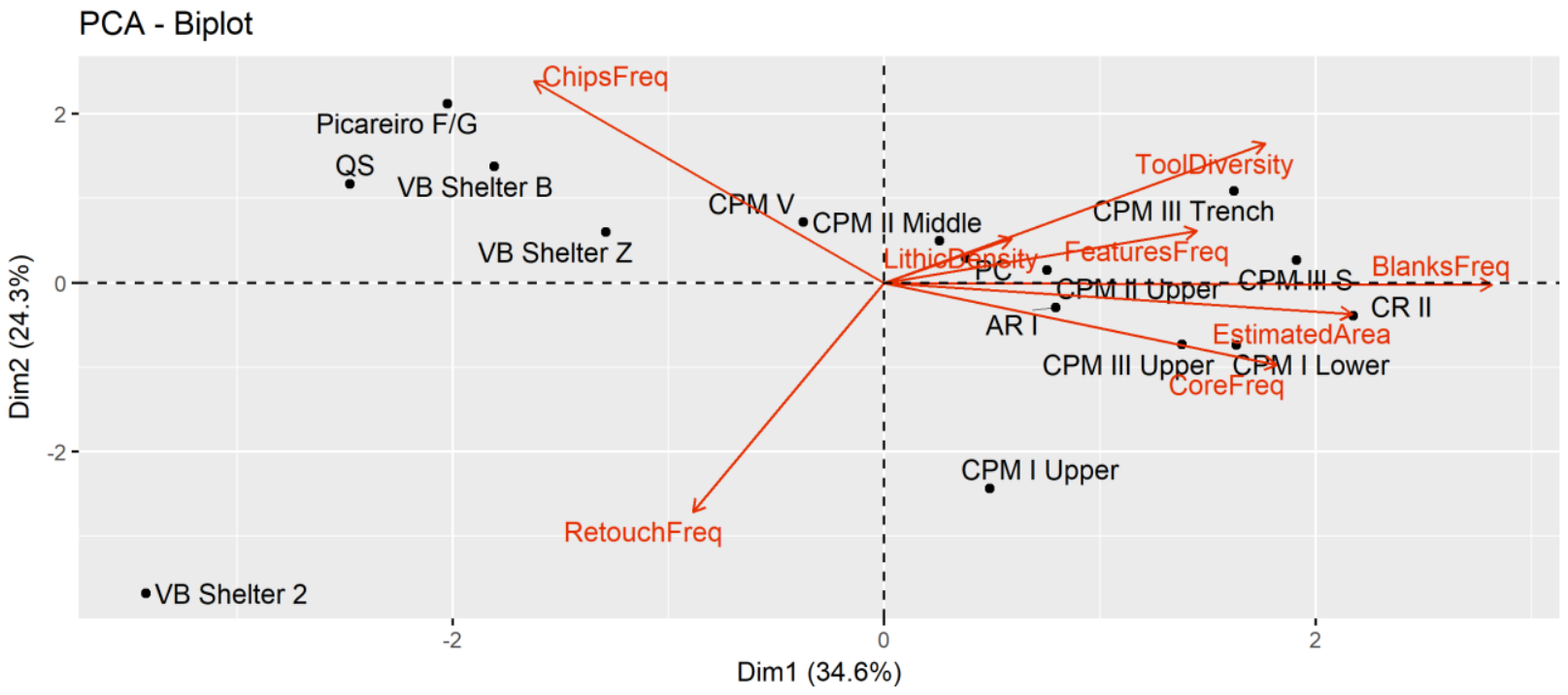

352 Figure 4 PCA Biplot for Dimensions 1 and 2

353

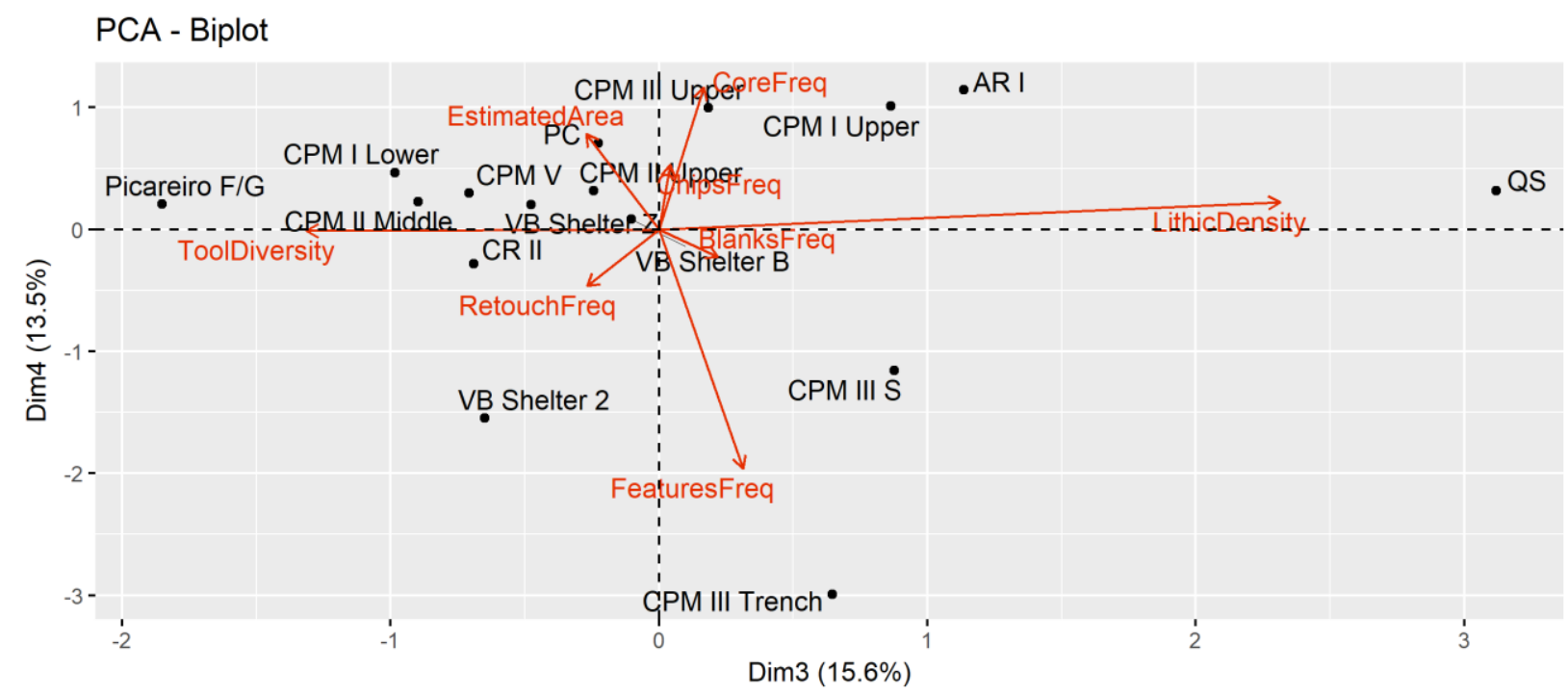

Figure 5 PCA Biplot for Dimensions 3 and 4

358 The results of our analysis indicate that, unlike what is specified by Clark and Barton (2017),

359 patterns revealed by the inverse relationship between retouch frequency and lithic volumetric 
360 density are not always consistent with specific durations of site occupation. Assemblages

361 classified under the traditional concepts of expedient and curated technologies may not

362 necessarily be associated with the time spent at a specific site by human groups.

363 The best example in this regard are the results obtained for the context of QS. This is a fully

364 excavated context, for which a detailed refitting analysis (Almeida 2000) revealed that a small

365 number of cobbles were exploited for the production of elongated products, and that while the

366 artifact sample is dominated by cortical flakes, cores, and several maintenance elements, a great

367 number of produced blades and bladelets seem to have been exported (Bicho 2005). All these

368 characteristics, together with its location directly on top of a flint source, indicate that QS was a

369 knapping workshop context, used for a short period of time, and most certainly within a

370 logistically organized settlement system. As in this case, sites whose primary functionality was

371 raw material provisioning and served as knapping workshops will certainly present all the

372 characteristics expected from expedient lithic assemblages: low incidence of retouched pieces,

373 high number of blanks, few exhausted cores, among others. Most of these sites, however, were

374 occupied during short periods of time. In these cases, an index calculated based on retouch

375 frequency is impractical to determine occupation length, with retouched tools being imported in

376 small numbers, and onsite retouched debitage products exported to other locations.

377 Similarly, sites which were occupied as field camps, using Binford's terminology that define

378 these as "temporary operational center[s] for task groups [...], where a task group sleeps, eats,

379 and otherwise maintains itself while away from the residential base" (Binford 1980: 10), can be

380 associated with both expedient or curated assemblages, depending on a complex set of

381 particularities, of which availability of usable raw materials is a central one. The differences

382 introduced by Kuhn's (1995) concepts of "provisioning of places" and "provisioning of

383 individuals" are fundamental in this regard, distinguishing between strategies in which groups

384 supply themselves from immediately available resources and make tools on the spot, or they

385 anticipate their needs by transporting raw material blocks or already produced tools (Porraz

386 2009). This seems to be the case with the VB Shelter B context. Although occupying a fairly

387 small area of the site, a very large diversity of chert raw materials (Pereira et al. 2016), low

388 presence of cores and blanks, and high frequency of knapping residues (Cascalheira 2010, 2013),

389 indicate that this context was probably used multiple times as a temporary field camp, where the 
complex combination of in situ knapping and retooling activities, resulted in a rather typical expedient assemblage. Thus, expedient behaviors are not conditioned by the amount of time spent in a site, but as detailed by Nelson (1991) on the location of activities close to raw material sources (or stockpiling), the lack of time stress in tool manufacture, and the regular use of sites that allow people to take advantage of abundant, predictable, resources.

It is undeniable that the significant negative correlation between retouch frequency and lithic volumetric density can be a viable approach to look for the average technological options made within each context under study (see e.g. Villaverde et al. 1998; Riel-Salvatore and Barton 2004, 2007; Sandgathe 2005; Barton et al. 2013; Clark and Barton 2017). However, although the formula might excel at separating curated vs. expedient approaches, it cannot be always equated with a clear division between short-term logistic and long-term residential sites.

Also problematic in our opinion, is the dichotomy of "curated technologies = residential mobility" vs "expedient technologies = logistical mobility" as presented by, for example, RielSalvatore (2010). The case of VB Shelter 2, previously classified as a Gravettian point cache (Bicho et al. 2016), and whose location both in the WABI plot and in the PCA biplots revealed a highly curated assemblage, is particularly relevant in this context. Although rare in the Eurasian Paleolithic archaeological record (but see e.g. Aubry et al. 2003; Tabarev et al. 2013 for other examples), based on the ethnographic record cache contexts are thought to be "common components of a logistical strategy in that successful procurement of resources by relatively small groups for relatively large groups generally means large bulk" (Binford 1980: 12). It is true, though, that in the context of the classification of occupation duration, lithic caches offer an additional classificatory problem, since site use of these contexts can be classified as either a very short occupation (when the cache is placed at the specified location and picked up when needed), or as long-term occupations if considering the total amount of time that the cache is in use. Either way, a context like VB Shelter 2 is unlikely to be associated with a residential mobility strategy, possibly representing the shorter and more curated type of assemblages of a logistical system. From a different perspective, accepting that significant time investment (both in tool manufacture and use life) is an essential component in characterizing reliable assemblages (sensu Bleed 1986), frequently associated with high levels of curation, then the VB Shelter 2 does not seem to fit at all in that category. The set of small retouched and unretouched bladelets 
420 more plausibly fit a maintainable type of system, that in the WABI calculation are associated 421 with residential settlement systems. This particular contradiction mirrors the strong debate 422 carried over the years about the factors explaining the curated/expedient dichotomy (see Vaquero 423 and Romagnoli 2017 for a comprehensive review), and their repercussive implications for 424 settlement interpretation.

425 Although the set of variables used in our analysis seem to show a clearer pattern related to the 426 organization of lithic technology and its possible association with the duration of occupation, 427 there are a series of caveats that are still noteworthy in this context. Perhaps the most important 428 and more relevant one is the influence of repetition of occupations in a single context, 429 independently of its duration. The truth is that, in most cases, it is particularly difficult, if not 430 impossible, to separate two or more occupations in an archaeological palimpsest. It is likely that 431 is not fundamentally important if the various occupations of a site have similar durations and 432 functions - the final result in terms of a lithic assemblage will likely not change, at least in what 433 concerns the variables considered here. The only exception is lithic volumetric density, but we 434 have demonstrated that this is not a particularly helpful variable to separate short-term from 435 long-term occupations, since it can vary both in terms of the intensity of lithic exploitation but 436 also with the rather problematic sedimentation rates at the different contexts (Barton and Clark 437 1993; Farrand 2001; Stein et al. 2003; Riel-Salvatore and Barton 2004).

438 The problem raises when an archaeological palimpsest is the formation of diverse temporal and 439 functional occupations through time (Moncel and Rivals 2011). This situation will profoundly 440 alter variables such as the relation of chip-core/blank frequencies, as well as the diversity of tools 441 present across the sequence. Since the presence and frequency of features has a small weight, the 442 only other variable that may help on this context is that of the occupation area. Regrettably, the 443 area of an archaeological context can also be affected by a partial overlapping of two different 444 occupations, thus extending the range of artifact dispersion and material use at a single site. It 445 seems that a particularly interesting, but still underutilized (Goldberg and Aldeias 2018), way to 446 deal with this issue is that of contextualizing common macroscopic archaeological data with the 447 characterization of site formation processes based on micromorphological analyses of sediments, 448 where by virtue of microscopic view various time slices of occupation can be separated in a 449 given sampled area (with the inherent problems related to sample size present in each case). 
450 Lithic refitting might be another way to test the occurrence of several short-term occupation in 451 one specific context, but very specific preservation conditions are needed for this to occur, such 452 as in the outstanding case of Abric Romani (see Carbonell (2012) and featured articles). On the 453 other hand, when organic preservation is good enough, specific types of analyses of faunal 454 remains of anthropogenic origin can be used to estimate duration of occupation. Those are, 455 however, most times limited to the definition of seasonal vs. all year-round occupations (see e.g. 456 Manne 2014; Rivals et al. 2009a; b).

\section{Conclusion}

458 The present study focused on the use and application of the label "short-term occupation". We 459 used a diverse group of variables, based on different methods, to determine the relative length of 460 occupation of a set of 16 archaeological contexts, all dated to the Upper Paleolithic, and all 461 located in westernmost region of Iberia.

462 Drawing upon previous approaches to the relationship between lithics and settlement, our study 463 suggests that retouch frequency and lithic volumetric density are not as sensitive as argued for 464 the distinction of settlement systems and site occupancy modalities. Instead, when used in 465 conjunction, those variables most likely represent technological aspects within a very diverse 466 time frames of duration of occupations. A multivariate approach to our data revealed that other

467 variables, such as the frequency of chips, blanks and cores, or the diversity of retouched tools, 468 are more sensitive and more appropriate to distinguish between short-term and long-term 469 occupations and its association with strategies of lithic technology organization (i.e., curated $470 \quad$ vs. expedient).

471 We also note that, like all the dichotomous classification systems used to organize the 472 archaeological record, categorizing archaeological contexts as either short or long-term 473 occupations is an oversimplification of past complex reality. Paleolithic assemblages are most of 474 the times time-average constituents of sets of multiple and complex occupations. When 475 detectable, such as in the cases of some of the contexts used in our analysis, short-term 476 occupations are rather challenging to integrate with long-term ones and, with both, to build a 477 wider, consistent, and more pertinent portrait. 


\section{Acknowledgements}

479 We would like to thank Andrea Picin for inviting us to the SAA symposium on Short-term 480 Occupations, held in Vancouver, Canada in 2017, and the two anonymous reviewers whose 481 comentaries and suggestions helped to improve the final version of this paper.

482 We also would like to thank Fundação para Ciência e Tecnologia, for financial support on 483 various projects, including UID/ARQ/04211/2013 and PTDC/EPH-ARQ/4998/2012.

484 The sites in the Rio Maior region (ArI, CRII, CPM, PC and QS) were all excavated under 485 Anthony Marks' US National Science Foundation grant “The Prehistory of Portugal” \#8803789, 486 as well as with his direct supervision and participation.

\section{References}

488 Almeida F (2000) The terminal Gravettian of Portuguese estremadura: Technological variability 489 of the lithic industries. PhD Thesis, Southern Methodist University

490 Amick DS (1996) Regional patterns of Folsom mobility and land use in the American

491 Southwest. World Archaeology 27:411-426. doi:

492 https://doi.org/10.1080/00438243.1996.9980317

493 Aubry T, Peyrouse J-B, Walter B (2003) Les feuilles de laurier de Volgu (Saône-et-Loire): Une 494 énigme en partie résolue? PALEO Revue d'archéologie préhistorique 15:251-254

495 Barton CM (1990) Stone Tools and Paleolithic Settlement in the Iberian Peninsula. Proceedings 496 of the Prehistoric Society 56:15-32. doi: 10.1017/S0079497X00005004

497 Barton CM, Clark GA (1993) Cultural and natural formation processes in late Quaternary cave 498 and rockshelter sites of western Europe and the Near East. In: Goldberg P, Nash DT, Petraglia 499 MD (eds) Formation Processes in Archaeological Context. Prehistory Press, Madison, WI., pp $500 \quad 33-52$

501 Barton CM, Riel-Salvatore J (2014) The formation of lithic assemblages. Journal of 502 Archaeological Science 46:334-352. doi: 10.1016/j.jas.2014.03.031 
503 Barton CM, Villaverde V, Zilhão J et al (2013) In glacial environments beyond glacial terrains:

504 Human eco-dynamics in late Pleistocene Mediterranean Iberia. Quaternary International 318:53505 68. doi: 10.1016/j.quaint.2013.05.007

506 Bicho N (1994) The End of the Paleolithic and the Mesolithic in Portuga. Current Anthropology $507 \quad 35: 664-674$

508 Bicho N (2005) The extinction of Neanderthals and the emergence of the Upper Paleolithic in 509 Portugal. Promontoria 3:173-228

510 Bicho N (1993) Late Glacial prehistory of central and southern Portugal. Antiquity 67:761-775

511 Bicho N (1992) Technological change in the final upper paleolithic of Rio Maior, Portuguese

512 Estremadura. PhD thesis, Southern Methodist University.

513 Bicho N (2009) On the edge: Early Holocene adaptations in Southwestern Iberia. Journal of 514 Anthropological Research 65:185-206

515 Bicho N, Cascalheira J, Gonçalves C (2017a) Early Upper Paleolithic colonization across

516 Europe: Time and mode of the Gravettian diffusion. PLoS One 12:e0178506

517 Bicho N, Cascalheira J, Marreiros J, Pereira T (2017b) Rapid climatic events and long term 518 cultural change: The case of the Portuguese Upper Paleolithic. Quaternary International 428:351916

520 Bicho N, Haws J, Hockett B (2006) Two sides of the same coin—rocks, bones and site function 521 of Picareiro Cave, central Portugal. Journal of Anthropological Archaeology 25:485-499. doi:

522 10.1016/j.jaa.2006.03.009

523 Bicho N, Manne T, Marreiros J et al (2013) The ecodynamics of the first modern humans in 524 Southwestern Iberia: The case of Vale Boi, Portugal. Quaternary International 318:102-116. doi: 525 10.1016/j.quaint.2013.06.029

526 Bicho N, Marreiros J, Cascalheira J et al (2015) Bayesian modeling and the chronology of the 527 Portuguese Gravettian. Quaternary International 359-360:499-509. doi: 
529 Bicho N, Marreiros J, Cascalheira J, Raja M (2016) An Early Gravettian Point Cache from Vale 530 Boi: Implications for the Arrival of Anatomically Modern Humans to Southern Iberia. Paper 531 presented at 81st Annual Meeting of the Society for American Archaeology

532 Bicho N, Stiner MC, Lindly J (2004) Shell ornaments, bone tools and long distance connections 533 in the Upper Paleolithic of Southern Portugal. In: Otte M (ed) La Spiritualité - Actes du colloque 534 International de Liège. Études et Recherches Archéologiques de l'Université de Liège, Liège, pp $535 \quad 71-80$

536 Binford LR (1981) Bones: Ancient men and modern myths. Academic Press, New York

537 Binford LR (1978a) Dimensional analysis of behavior and site structure: Learning from an 538 Eskimo hunting stand. American Antiquity 43:330-361

539 Binford LR (1978b) Nunamiut ethnoarchaeology. Academic Press, New York

540 Binford LR (1982) The archaeology of place. Journal of Anthropological Archaeology 1:5-31

541 Binford LR (1980) Willow smoke and dogs' tails: Hunter-gatherer settlement systems and 542 archaeological site formation. American Antiquity 4-20

543 Bleed P (1986) The optimal design of hunting weapons: Maintainability or reliability. American 544 Antiquity 51:737-747

545 Bretzke K, Kandel AW, Conard NJ (2017) The Middle Paleolithic sequence of Wadi Mushkuna 546 Rockshelter and its implications for hominin settlement dynamics in western Syria. Quaternary 547 International 435:106-114

548 Carbonell E (ed) (2012) High resolution archaeology and Neanderthal behavior : Time and space 549 in Level J of Abric Romaní (Capellades, Spain) /. Springer, Dordrecht, Netherlands

550 Carvalho AF (2007) A neolitização do Portugal meridional: Os exemplos do Maciço calcário 551 estremenho e do Algarve ocidental. PhD thesis, Universidade do Algarve

552 Cascalheira J (2013) A influência mediterrânica nas redes sociais do Solutrense final peninsular. 553 Unpublished Ph.D. thesis, Universidade do Algarve

554 Cascalheira J (2010) Tecnologia lítica do abrigo Solutrense de Vale Boi. UNIARQ, Lisbon 
555 Cascalheira J, Bicho N (2015) On the Chronological Structure of the Solutrean in Southern

556 Iberia. PLoS One 10:e0137308. doi: 10.1371/journal.pone.0137308

557 Cascalheira J, Bicho N (2013) Hunter-gatherer ecodynamics and the impact of the Heinrich

558 event 2 in Central and Southern Portugal. Quaternary International 318:117-127. doi:

559 10.1016/j.quaint.2013.05.039

560 Clark GA, Barton CM (2017) Lithics, landscapes \& la Longue-durée - Curation \& expediency as 561 expressions of forager mobility. Quaternary International 450:137-149. doi:

562 10.1016/j.quaint.2016.08.002

563 Crassard R, Petraglia MD, Drake NA et al (2013) Middle Palaeolithic and Neolithic Occupations 564 around Mundafan Palaeolake, Saudi Arabia: Implications for Climate Change and Human 565 Dispersals. PLoS One 8:e69665. doi: 10.1371/journal.pone.0069665

566 Dillehay T, Stackelbeck K, Rossen J, Maggard G (2011) Research History, Methods, and Site 567 Types. In: Dillehay TD (ed) From foraging to farming in the Andes: New perspectives on food 568 production and social organization. Cambridge University Press, Cambridge, pp 29-41

569 Farrand WR (2001) Sediments and stratigraphy in rockshelters and caves: A personal perspective 570 on principles and pragmatics. Geoarchaeology 16:537-557

571 Goldberg P, Aldeias V (2018) Why does (archaeological) micromorphology have such little 572 traction in (geo) archaeology? Archaeological and Anthropological Sciences 10:269-278

573 Grove M (2009) Hunter-gatherer movement patterns: Causes and constraints. Journal of 574 Anthropological Archaeology 28:222-233. doi: 10.1016/j.jaa.2009.01.003

575 Haws JA (2012) Paleolithic socionatural relationships during MIS 3 and 2 in central Portugal. 576 Quaternary International 264:61-77. doi: 10.1016/j.quaint.2011.10.003

577 Kelly RL (1995) The foraging spectrum. Smithsonian Institution Press, Washington DC 578 Kuhn SL (1992) On planning and curated technologies in the Middle Paleolithic. Journal of 579 Anthropological Research 48:185-214

580 Kuhn SL (1995) Mousterian Lithic Technology. Princeton University Press 
581 Lê S, Josse J, Husson F (2008) FactoMineR: An R package for multivariate analysis. Journal of 582 statistical software 25:1-18

583 Madsen DB, Haizhou M, Brantingham PJ et al (2006) The late Upper Paleolithic occupation of 584 the northern Tibetan Plateau margin. Journal of Archaeological Science 33:1433-1444

585 Manne T (2014) Early Upper Paleolithic bone processing and insights into small-scale storage of 586 fats at Vale Boi, southern Iberia. Journal of Archaeological Science 43:111-123. doi:

$587 \quad 10.1016 / j$.jas.2013.12.003

588 Marks AE, Bieho N, Zilhão J, Reid Ferring C (1994) Upper Pleistocene prehistory in Portuguese 589 Estremadura: Results of preliminary research. Journal of Field Archaeology 21:53-68

590 Marreiros J, Bicho N (2013) Lithic technology variability and human ecodynamics during the 591 Early Gravettian of Southern Iberian Peninsula. Quaternary International 318:90-101. doi: 592 10.1016/j.quaint.2013.05.008

593 Marwick B (2016) Computational Reproducibility in Archaeological Research: Basic Principles 594 and a Case Study of Their Implementation. Journal of Archaeological Method and Theory 595 24:424-450. doi: 10.1007/s10816-015-9272-9

596 Marwick B, Boettiger C, Mullen L (2017) Packaging data analytical work reproducibly using R 597 (and friends). The American Statistician 0-0. doi: 10.1080/00031305.2017.1375986

598 McCall GS (2007) Behavioral ecological models of lithic technological change during the later 599 Middle Stone Age of South Africa. Journal of Archaeological Science 34:1738-1751. doi:

$600 \quad 10.1016 / j$.jas.2006.12.015

601 McCall GS (2006) Multivariate perspectives on change and continuity in the Middle Stone Age 602 lithics from Klasies River Mouth, South Africa. Journal of Human Evolution 51:429-39. doi: 603 10.1016/j.jhevol.2006.06.003

604 McPherron SP (1994) A reduction model for variability in Acheulian biface morphology. PhD 605 Thesis, University of Pennsylvania

606 Mendonça CI da S (2009) A tecnologia lítica no Tardiglaciar do Algarve. PhD thesis 
607 Moncel M-H, Rivals F (2011) On the question of short-term neanderthal site occupations: Payre, 608 France (MIS 8-7), and Taubach/Weimar, Germany (MIS 5). Journal of Anthropological

609 Research 67:47-75. doi: 10.3998/jar.0521004.0067.104

610 Nelson MC (1991) The study of technological organization. Archaeological method and theory $6113: 57-100$

612 Nishiaki Y, Akazawa T (2015) Patterning of the early Middle Paleolithic occupations at Douara 613 Cave and its implications for settlement dynamics in the Palmyra basin, Syria. L'Anthropologie $614 \quad 119: 519-541$

615 Pereira T, Bicho N, Cascalheira J et al (2016) Territory and abiotic resources between 33 and $61615.6 \mathrm{ka}$ at Vale Boi (SW Portugal). Quaternary International 412, Part A:124-134. doi:

617 http://dx.doi.org/10.1016/j.quaint.2015.08.071

618 Picin A (2017) Short-term occupations at the lakeshore: A technological reassessment of the 619 open-air site Königsaue (Germany). Quartär 63:7-32. doi: 10.7485/QU63_1

620 Porraz G (2009) Middle Paleolithic mobile toolkits in shortterm human occupations: Two case 621 studies. Eurasian Prehistory 6:33-55

622 R Core Team (2013) R: A Language and Environment for Statistical Computing. R Foundation 623 for Statistical Computing, Vienna, Austria

624 Riel-Salvatore J (2010) A Niche Construction Perspective on the Middle-Upper Paleolithic 625 Transition in Italy. Journal of Archaeological Method and Theory 17:323-355. doi:

626 10.1007/s10816-010-9093-9

627 Riel-Salvatore J, Barton CM (2004) Late Pleistocene technology, economic behavior, and land628 use dynamics in southern Italy. American Antiquity 69:257-274

629 Riel-Salvatore J, Barton CM (2007) New quantitative perspectives on the Middle-Upper 630 Paleolithic transition: The view from the northern Mediterranean. BAR International Series $631 \quad 1620: 61$

632 Rios-Garaizar J (2016) Early Middle Palaeolithic occupations at Ventalaperra cave (Cantabrian 633 Region, Northern Iberian Peninsula). Journal of Lithic Studies 3:161-183 
634 Rivals F, Moncel M-H, Patou-Mathis M (2009a) Seasonality and intra-site variation of

635 Neanderthal occupations in the Middle Palaeolithic locality of Payre (Ardèche, France) using

636 dental wear analyses. Journal of Archaeological Science 36:1070-1078. doi:

$637 \quad 10.1016 /$ j.jas.2008.12.009

638 Rivals F, Schulz E, Kaiser TM (2009b) A new application of dental wear analyses: Estimation of 639 duration of hominid occupations in archaeological localities. Journal of Human Evolution 640 56:329-339. doi: 10.1016/j.jhevol.2008.11.005

641 Sahlins M (1972) Stone age economics. Aldine-Atherton, Chicago

642 Sandgathe DM (2005) Examining the Levallois reduction strategy from a design theory point of 643 view. John; Erica Hedges

644 Schiffer MB (1983) Toward the identification of formation processes. American Antiquity $645 \quad 48: 675-706$

646 Schiffer MB (1987) Formation processes of the archaeological record. University of New 647 Mexico Press, Albuquerque, New Mexico

648 Shennan S (1997) Quantifying archaeology. University of Iowa Press

649 Stein JK, Deo JN, Phillips LS (2003) Big Sites—Short Time: Accumulation Rates in

650 Archaeological Sites. Journal of Archaeological Science 30:297-316. doi:

$651 \quad 10.1006 /$ jasc. 2002.0838

652 Tabarev AV, Gillam JC, Kanomata Y, Gunchinsuren B (2013) A Paleolithic cache at tolbor

653 (Northern Mongolia). Archaeology, Ethnology and Anthropology of Eurasia 41:14-21

654 Terradillos-Bernal M, Fernández-Lomana JCD, Pardo J-FJ et al (2017) San Quirce (Palencia, 655 Spain). A Neanderthal open air campsite with short term-occupation patterns. Quaternary 656 International 435:115-128. doi: 10.1016/j.quaint.2015.09.082

657 Vaquero M, Romagnoli F (2017) Searching for Lazy People: The Significance of Expedient 658 Behavior in the Interpretation of Paleolithic Assemblages. Journal of Archaeological Method and 659 Theory 25:1-34. doi: 10.1007/s10816-017-9339-x 
660 Villaverde V, Aura JE, Barton CM (1998) The Upper Paleolithic in Mediterranean Spain: A

661 review of current evidence. Journal of World Prehistory 12:121-198

662 Wickham H (2015) R packages: Organize, test, document, and share your code. O'Reilly Media, 663 Inc., Sebastopol, CA

664 Yellen JE (1977) Archaeological approaches to the present: Models for reconstructing the past.

665 Academic Press, New York

666 Zilhão J (1997) O Paleolítico Superior da Estremadura portuguesa. Colibri, Lisbon 
668 This report was generated on 2018-06-06 20:27:26 using the following computational 669 environment and dependencies:

\begin{tabular}{|c|c|c|c|c|c|}
\hline 670 & \#> & setting & \multicolumn{3}{|l|}{ value } \\
\hline 671 & \#> & version & \multicolumn{3}{|c|}{$R$ version $3.4 .4(2018-03-15)$} \\
\hline 672 & \#> & system & \multicolumn{3}{|l|}{ x86_64, mingw32 } \\
\hline 673 & \#> & ui & \multicolumn{3}{|l|}{ RTerm } \\
\hline 674 & \#> & language ( & \multicolumn{3}{|l|}{$(E N)$} \\
\hline 675 & \#> & collate & English_United & States.125 & \\
\hline 676 & \#> & $\mathrm{tz}$ & \multicolumn{3}{|l|}{ Europe/London } \\
\hline 677 & \#> & date & \multicolumn{3}{|l|}{$2018-06-06$} \\
\hline 678 & \#> & & & & \\
\hline 679 & \#> & package & * version & date & source \\
\hline 680 & \#> & assertthat & 0.2 .0 & $2017-04-11$ & L CRAN (R 3.4.4) \\
\hline 681 & \#> & backports & 1.1 .2 & $2017-12-13$ & 3 CRAN (R 3.4.3) \\
\hline 682 & \#> & base & $* 3.4 .4$ & $2018-03-15$ & local \\
\hline 683 & \#> & bindr & 0.1 .1 & $2018-03-13$ & 3 CRAN (R 3.4.4) \\
\hline 684 & \#> & bindrcpp & 0.2 .2 & $2018-03-29$ & 9 CRAN (R 3.4.4) \\
\hline 685 & \#> & bookdown & 0.7 & $2018-02-18$ & 3 CRAN ( $\mathrm{R} 3.4 .4)$ \\
\hline 686 & \#> & cluster & 2.0 .6 & $2017-03-10$ & CRAN (R 3.4.4) \\
\hline 687 & \#> & colorspace & $1.3-2$ & $2016-12-14$ & 4 CRAN (R 3.4.4) \\
\hline 688 & \#> & compiler & 3.4 .4 & $2018-03-15$ & local \\
\hline 689 & \#> & cowplot & 0.9 .2 & $2017-12-17$ & 7 CRAN (R 3.4.4) \\
\hline 690 & \#> & datasets & $* 3.4 .4$ & $2018-03-15$ & 5 local \\
\hline 691 & \#> & devtools & 1.13 .5 & $2018-02-18$ & 3 CRAN (R 3.4.3) \\
\hline 692 & \#> & digest & 0.6 .15 & $2018-01-28$ & 3 CRAN (R 3.4.3) \\
\hline 693 & \#> & dplyr & $* 0.7 .5$ & $2018-05-19$ & (9RAN (R 3.4.4) \\
\hline 694 & \#> & evaluate & 0.10 .1 & $2017-06-24$ & CRAN (R 3.4.4) \\
\hline 695 & \#> & factoextra & $* 1.0 .5$ & $2017-08-22$ & CRAN (R 3.4.4) \\
\hline 696 & \#> & FactoMineR & * 1.41 & $2018-05-04$ & 4 CRAN (R 3.4.4) \\
\hline 697 & \#> & flashClust & $1.01-2$ & $2012-08-21$ & L CRAN (R 3.4.1) \\
\hline 698 & \#> & ggplot2 & $* 2.2 .1$ & $2016-12-30$ & CRAN (R 3.4.4) \\
\hline
\end{tabular}




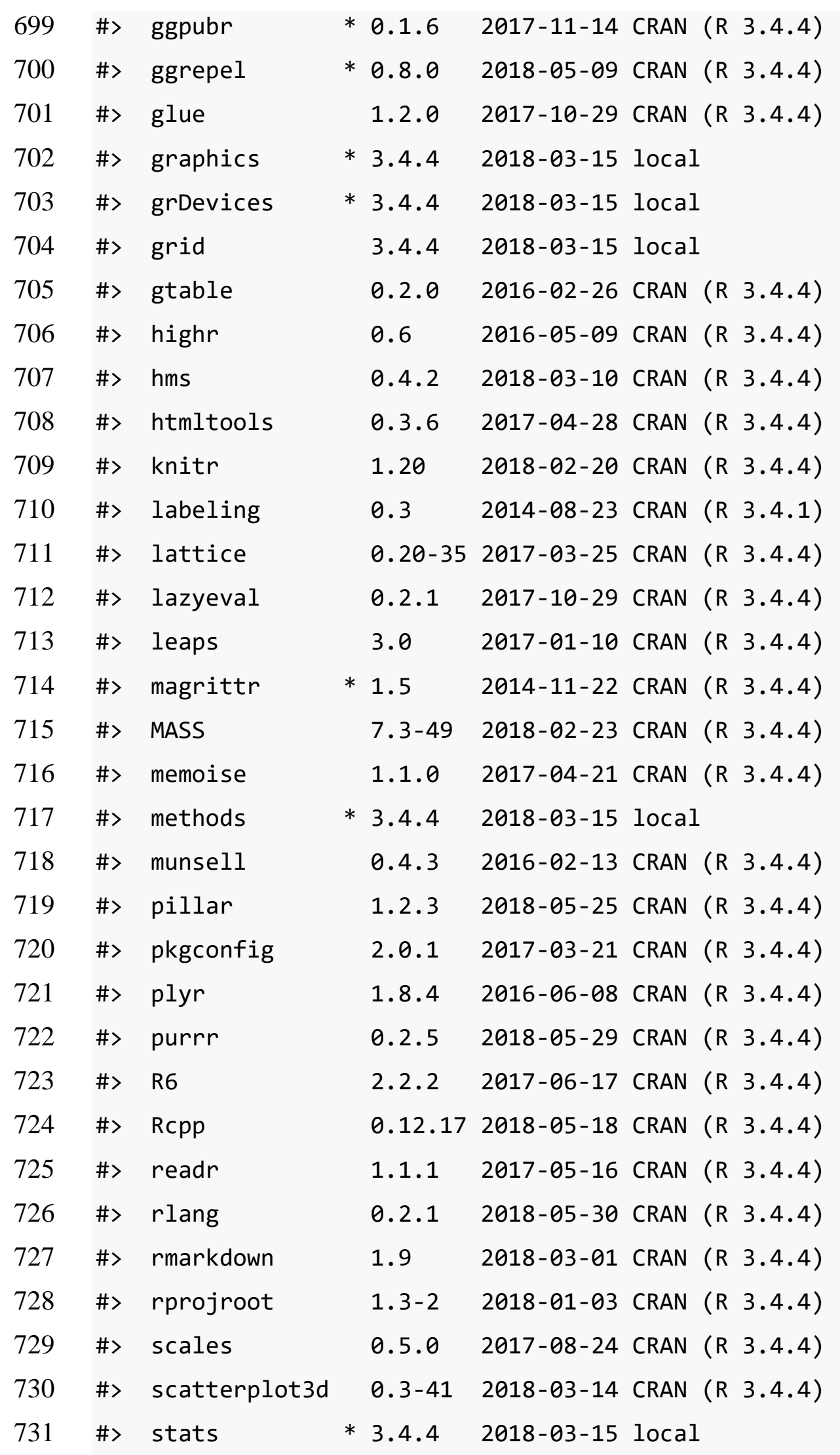




$\begin{array}{lll}732 & \text { \#> } & \text { stringi } \\ 733 & \text { \#> } & \text { stringr } \\ 734 & \text { \#> } & \text { tibble } \\ 735 & \text { \#> } & \text { tidyselect } \\ 736 & \text { \#> } & \text { tools } \\ 737 & \text { \#> } & \text { utils } \\ 738 & \text { \#> } & \text { withr } \\ 739 & \text { \#> } & \text { xfun } \\ 740 & \text { \#> } & \text { yaml }\end{array}$

1.1.7 2018-03-12 CRAN ( $R$ 3.4.4)

1.3.1 2018-05-10 CRAN ( $R$ 3.4.4)

1.4.2 2018-01-22 CRAN ( $R$ 3.4.4)

0.2.4 2018-02-26 CRAN ( $R$ 3.4.4)

3.4.4 2018-03-15 local

* 3.4.4 2018-03-15 local

2.1.2 2018-03-15 CRAN ( $R$ 3.4.4)

0.1 2018-01-22 CRAN ( $R$ 3.4.4)

2.1.19 2018-05-01 CRAN ( $R$ 3.4.4) 